$4 / 194050$

PPPL-3014 UC-424
PREPARED FOR THE U.S. DEPARTMENT OF ENERGY, UN̉DER CONTRACT DE-AC02-76-CHO-3073

PPPL-3014

\title{
TRITIUM PROCESSING AND MANAGEMENT DURING D-T EXPERIMENTS ON TFTR
}

\author{
BY
}

P.H. LA MARCHE, J.L. ANDERSON, C.A. GENTILE, ET AL.

\author{
NOVEMBER 1994
}

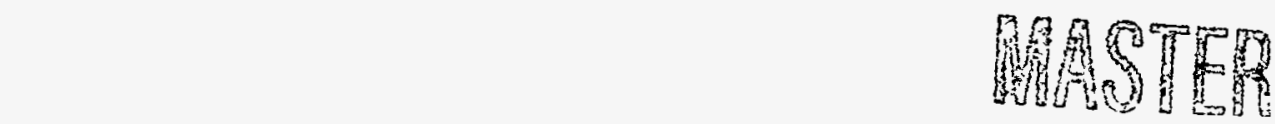

DISTRIBUTION OF THISOOGUKMENT IS UNLIMITED

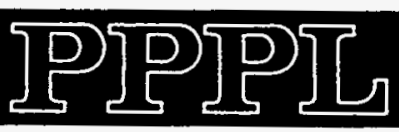

PRINCETON

PLASMA PHYSICS

LABORATORY

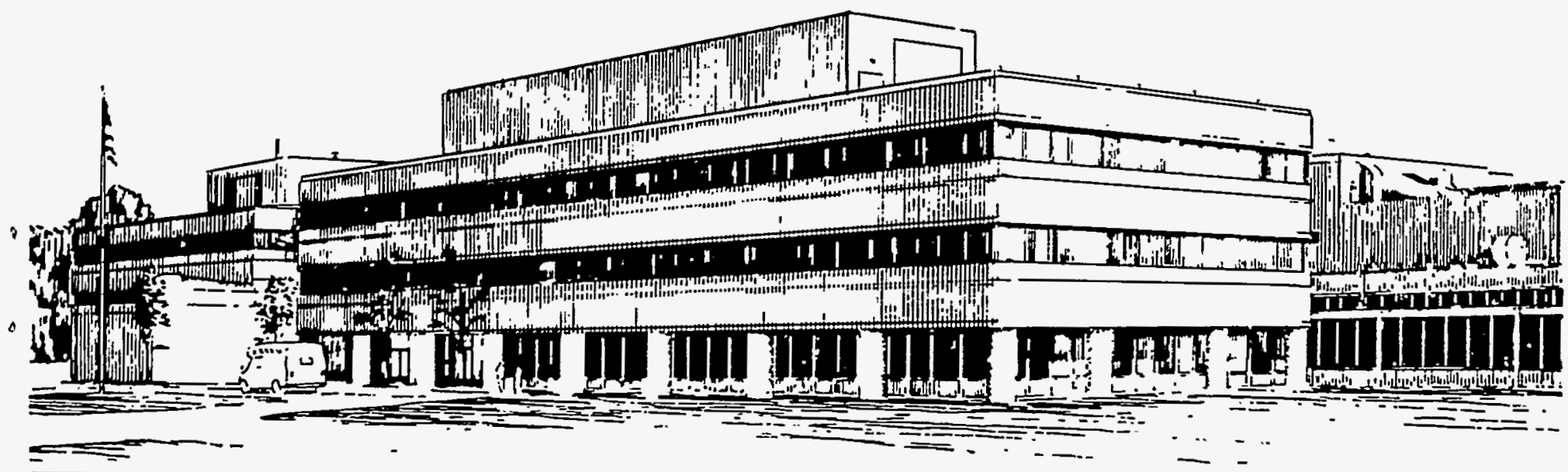

PRINCETON UNIVERSITY, PRINCETON, NEW JERSEY 


\section{NOTICE}

This report was prepared as an account of work sponsored by an agency of the United States Government. Neither the United States Government nor any agency thereof, nor any of their employees, makes any warranty, express or implied, or assumes any legal liability or responsibility for the accuracy, completeness, or usefulness of any information, apparatus, product, or process disclosed, or represents that its use would not infringe privately owned rights. Reference herein to. any specific commercial produce, process, or service by trade name, trademark, manufacturer, or otherwise, does not necessarily constitute or imply its endorsement, recommendation, or favoring by the United States Government or any agency thereof. The views and opinions of authors expressed herein do not necessarily state or reflect those of the United States Government or any agency thereof.

\section{NOTICE}

This report has been reproduced from the best available copy. Available in paper copy and microfiche.

Number of pages in this report: 9

DOE and DOE contractors can obtain copies of this report from:

Office of Scientific and Technical Information

P.O. Box 62

Oak Ridge, TN 37831 ;

(615) $576-8401$.

This report is publicly available from the:

National Technical Information Service

Department of Commerce

5285 Port Royal Road

Springfield, Virginia 22161

(703) $487-4650$ 


\section{DISCLAIMER}

Portions of this document may be illegible in electronic image products. Images are produced from the best available original document. 


\title{
TRITIUM PROCESSING AND MANAGEMENT DURING D-T EXPERIMENTS ON TFTR
}

\author{
P.H. La Marche, J.L. Anderson, C.A. Gentile, R.J. Hawryluk, J. Hosea, M. Kalish, T. Kozub, \\ H. Murray, A. Nagy, S. Raftopoulos, R.L. Rossmassler, R.A.P. Sissingh, J. Swanson, F. Tulipano, \\ M. Viola, D.R. Voorhees, R.T. Walters and the TFTR Team
}

\author{
Plasma Physics Laboratory \\ Princeton University \\ P.O. Box 451, Princeton, New Jersey 08543
}

\begin{abstract}
TFTR performance has surpassed many of the previous tokamak records. This has been made possible by the use of tritium as fuel for DT plasma discharges. Stable operations of tritium systems provide for safe, routine DT operation of TFTR. In the preparation for DT operation, in the commissioning of the tritium systems and in the operation of the Nuclear Facility several key lessons have been learned. They include: the facility must take the lead in interpreting the applicable regulations and orders and then seek regulator approval; the use of ultra high vacuum technology in tritium system design and construction simplifies and enhances operations and maintenance; and central facility control under a single supervisory position is crucial to safely orchestrate operational and maintenance activities.
\end{abstract}

\section{INTRODUCTION}

The Tokamak Fusion Test Reactor (TFTR) has achieved world record performance utilizing tritium during DT operation. Recent results for DT operation are: peak fusion power of $9 \mathrm{MW}$, $\mathrm{n}_{\mathrm{i}}(0) \tau_{\mathrm{E}} \mathrm{T}_{\mathrm{i}}(0)$ of about $5.2 \times 10^{20} \mathrm{~m}^{-3} *_{\mathrm{s}} * \mathrm{keV}$, stored energy of $6.5 \mathrm{MJ}$, energy confinement time $\left(\tau_{\mathrm{E}}\right)$ of $0.24 \mathrm{~s}$ (best $0.28 \mathrm{~s}$ ), Ti $(0) \sim 40 \mathrm{keV}$ and $\mathrm{Te}(0) \sim 11.5 \mathrm{keV}$, central fusion power density $1.8 \mathrm{MW} \mathrm{m} \mathrm{m}^{-3}$ and fusion energy per pulse of 6 MJ. For more detail, see Reference 1.

TFTR tritium systems have had a challenging history, Ref. 2. Designed in the 70's and installed in the early 80 's, the systems do not have the benefit of ultra high vacuum or tritium equipment that has been developed and marketed in the intervening years. The system was initially commissioned with deuterium in 1993 and final commissioning with tritium in late 1993 and early 1994. In this paper we will briefly describe the systems and discuss the problems and lessons learned associated with preparation for achieving Nuclear Facility status and for commissioning and maintenance of the systems.

\section{TRITIUM SYSTEMS CONFIGURATION}

Figure 1 schematically shows the fueling path for the TFTR tritium systems. In a typical shipment, 10 to $20 \mathrm{kCi}$ of tritium is delivered to TFTR in an a container, called an LP-50, specifically approved for its use by the US Department of Transportation (DOT). With a nominal volume of $50 \mathrm{l}$, the product container, with approximately 100 torr of tritium gas, is loaded into the Tritium Receiving and Analytical Glove Box (TRAGB), which is a part of the Tritium Storage and Delivery System (TSDS). The tritium is transferred to one of three uranium getter beds for storage. Once tritium is requested, the U-bed to be used is

This paper was presented at the 1994 American Nuclear Society Meeting, New Orleans, LA, June 1994.

To be published in Nuclear Fusion. 


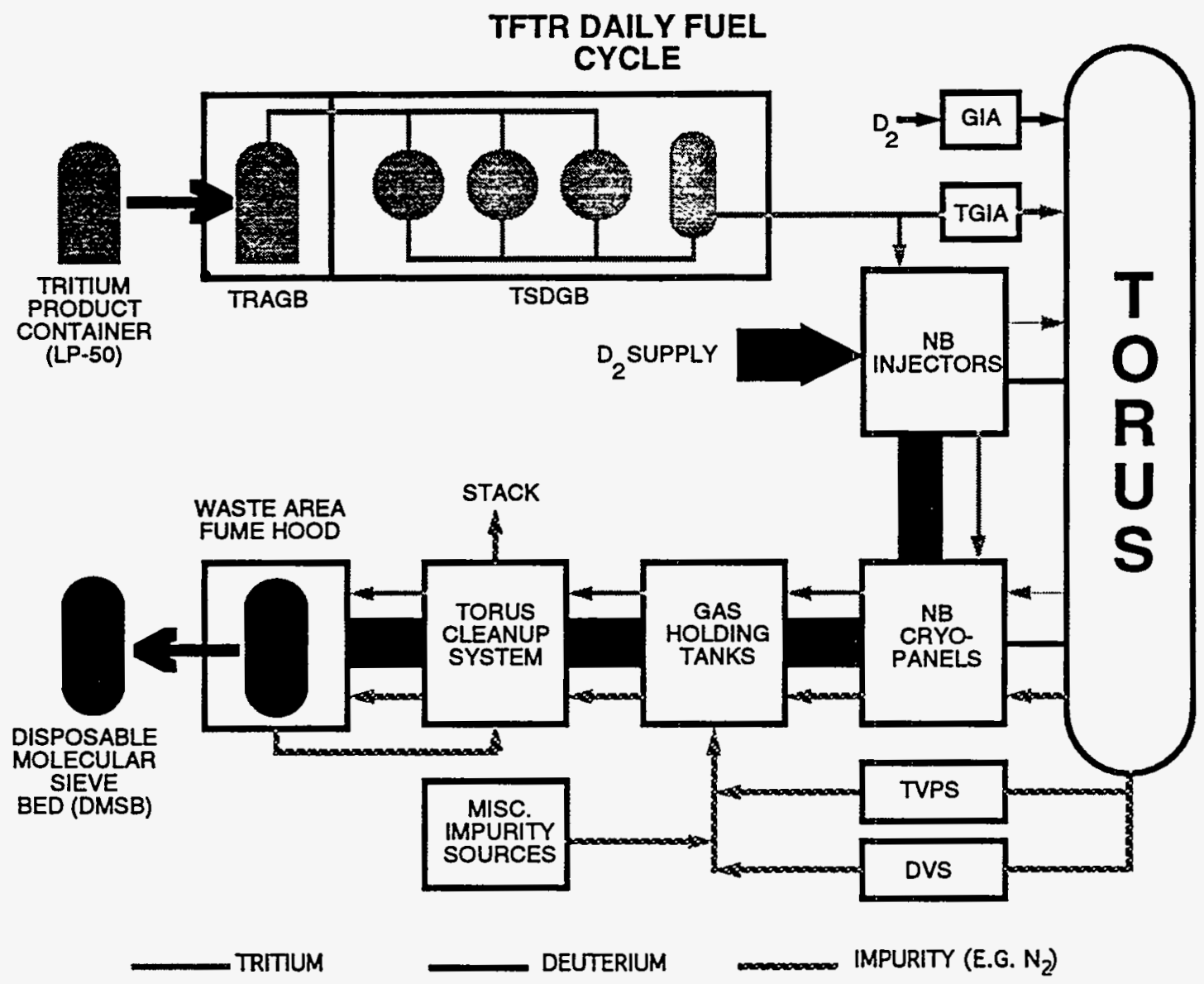

Figure 1. TFTR Daily Fuel Cycle. The flow of hydrogenic species through TFTR. The line widths are related to the relative amount of hydrogenic gas moved between systems. As can be seen, much more deuterium is supplied to the neutral beams than tritium. Of all of the gas delivered to the NBIs, less than $5 \%$ is injected. See text for explanation and key to acronyms.

heated, driving off the tritium. The tritium is sent to a calibrated volume, where the temperature and pressure of the gas is measured and inventoried (PVT measurement for pressure volume and temperature, which is related to the number of tritium molecules by the Ideal Gas Law.) The gas may be analyzed for purity at this point by a quadrupole mass spectrometer (QMS).

The tritium gas is then delivered to the Tritium Gas Delivery Manifold (TGDM). This supply line is coaxial in construction with the inner conductor comprised of a capillary line with a $1.6 \mathrm{~mm}$ inner diameter. The outer, secondary containment is $13 \mathrm{~mm}$ tubing and is under vacuum. An ion gauge and a QMS monitors this vacuum and delivery of tritium is inhibited if vacuum is lost or if mass 6 ( $\left.\mathrm{T}_{2}\right)$ components are observed. The small inner diameter is employed to minimize the tritium inventory in this $120 \mathrm{~m}$ line. The tritium is supplied by the TGDM to the Tritium Gas Injection Assemblies (TGIAs) and the NB Tritium Gas Injectors (NBTGIs), Fig. 2.

The two TGIAs provide direct injection of tritium gas into the torus. These have been used for transport studies (Ref. 1) but are rarely used for fueling plasma discharges (shots).

The primary method for fueling TFTR plasma discharges is by the Neutral Beam Injectors. For a typical DT plasma discharge, 


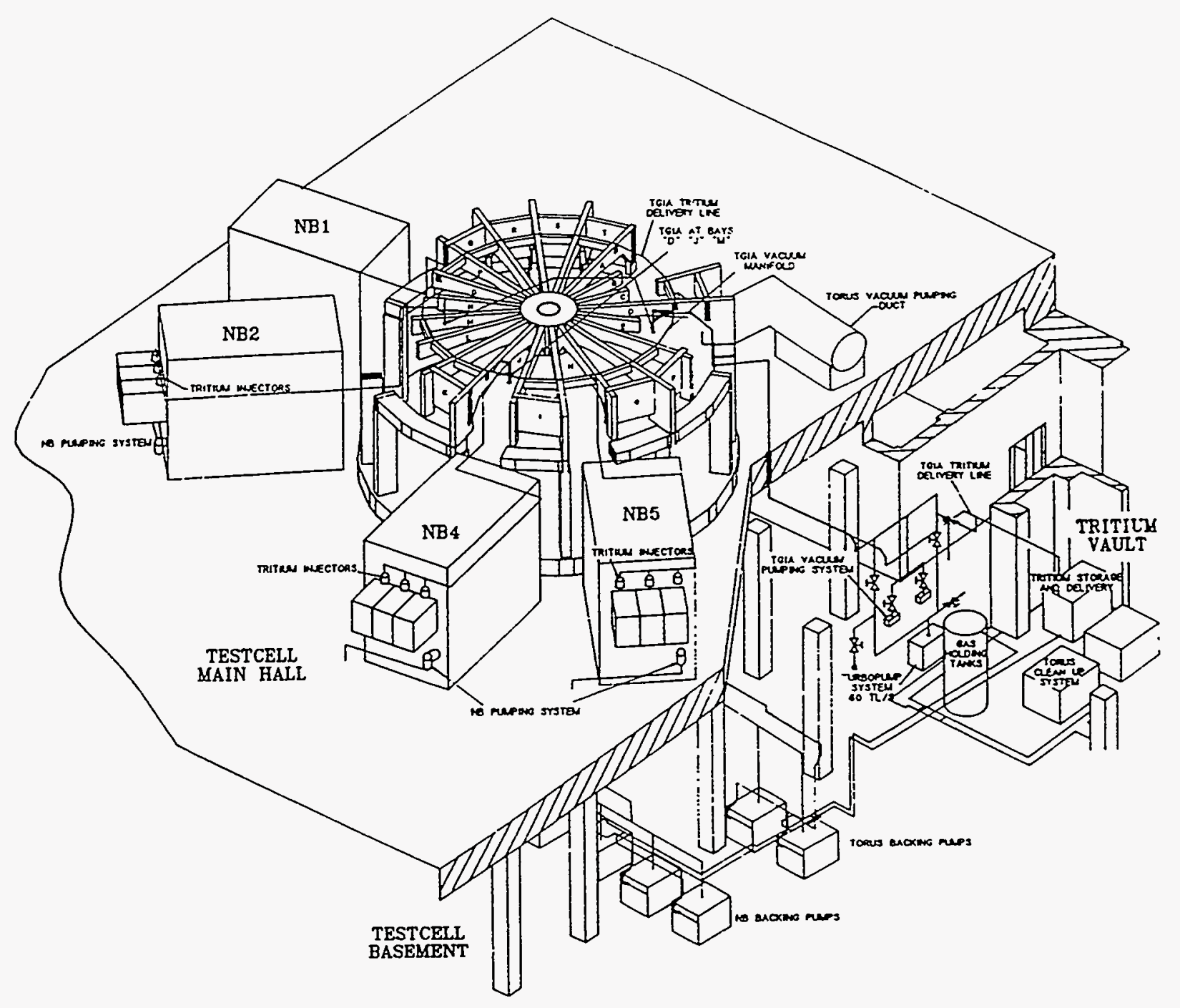

Figure 2. Projection view of the TFTR Tritium Systems. The TSDS is located in the basement in the Tritium Vault. A coaxial line carries the tritium to the two TGIAs for direct injection into the torus and to the 12 ion sources, three on each neutral beam (NB). For a typical DT shot $\approx 5 \mathrm{kCi}$ of tritium is loaded into six of the NBI and the remaining six are charged with deuterium.

six of the twelve ion sources are fueled with tritium and the other six are fueled with deuterium. The tritium inventory in the sources prior to the shot is $=5-6 \mathrm{kCi}$. The gas is injected into the ion source, where a fraction is accelerated and a larger fraction enters the neutral beam line and acts to neutralize about one-half of the accelerated beam. The neutral beam line enclosures contain boiling liquid helium cooled cryopanels that pump more than $95 \%$ of the gas injected into the ion source. This means that less than $5 \%$ of the gas delivered to the source for a shot is actually injected into a plasma discharge. Subsequent to the shot the cryopanels pump the gas particles from the discharge along with any impurities that were generated. During the time between shots, the ion sources are conditioned every 2.5 minutes using pulses of deuterium gas, which is also collected on the cryopanels. Because of this extensive conditioning, the fraction of the total gas that is injected into the beam line is only about $1 \%$ tritium.

Once operation of the machine is complete for the day, the neutral beam cryopanels are regenerated by warming them up to a temperature where the hydrogenic species are evaporated and pumped into the Gas Holding Tanks (GHTs) in the tritium area.

Gas from the torus is directly pumped to the GHTs through the Torus Vacuum Pumping System (TVPS). This system is only used 
during non-operational periods, being valved off during plasma discharge operations and, hence, a very small fraction $(\approx 1 \%)$ of the gas from the torus, primarily outgassing, is transported to the holding tanks via the TVPS. Another channel to the GHTs is through the several diagnostic devices that are open to the torus during plasma discharge operation. The aggregate gas load from these Diagnostic Vacuum Systems (DVS) is small $(<1 \%)$ due to the limited conductance of these systems to the torus.

The gas in the GHTs is composed of the regenerated fueling gas (99\% deuterium, $1 \%$ tritium) and assorted other impurity gas such as nitrogen (from purging) and hydrocarbons generated in the tokamak. The gases are pumped into the process stream, $4 \%$ gas from the GHTs into the working gas (nitrogen), of the Torus Cleanup System (TCS). The process gas is pumped over catalyst, which oxidizes the active components, forming moisture. The process stream is then passed through Disposable Molecular Sieve Beds (DMSBs). The moisture, containing the tritium oxide is deposited on the DMSB. The gas is passed over a second DMSB and through a large fixed molecular sieve bed. This ensures that only a small fraction of the original tritium remains in the process stream $(<0.1 \%$.) A small amount of the de-tritiated process gas is then vented to the stack. The process gas is then returned to the start of the TCS loop.

There are two types of DMSBs: Type A, which is used to bury the tritium waste has a limit of $1 \mathrm{kCi}$ of tritium and $3.6 \mathrm{~kg}$ of water; and Type $B$, which is used to store the tritium until it is removed and reprocessed at the Savannah River Site. The Type B DMSB has a limit of $25 \mathrm{kCi}$ of tritium and $3.2 \mathrm{~kg}$ of water.

To date, we have received approximately $200 \mathrm{kCi}$ of tritium, of which approximately $134 \mathrm{kCi}$ has been shipped off-site $(32 \mathrm{kCi}$ as elemental and $102 \mathrm{kCi}$ as oxide). The total amount of tritium delivered into the machine has been about $107 \mathrm{kCi}$ and approximately $120 \mathrm{kCi}$ has been processed into oxide.

\section{LESSONS LEARNED}

\section{A. Preparing for D-T Operations}

DOE has three levels of Hazard Classification: Category 1, High - significant off-site consequences; Category 2, Moderate significant on-site consequences; Category 3 , low - local (immediate worker) consequences. TFTR is classified as a Low Hazard Facility due to the fact that the on-site inventory is less than $300 \mathrm{kCi}$. The total on-site releasable (i.e. not sealed in DOT approved shipping containers) tritium inventory is administratively limited to no more than $50 \mathrm{kCi}$. Furthermore, the design basis accident fixes another administrative limit of no more than $25 \mathrm{kCi}$ that is releasable in any one place. These two limitations comprise the only limits in our Technical Safety Requirement (TSR) document. The requirements for TSRs are discussed in US DOE Order 5480.22 and are patterned after the technical specifications for fission reactors. Because of the very low risk of harm from D-T Operations, there are no safety class systems at TFTR. There are no specific regulations/orders for low hazard facilities. This makes for problematic review of the facility because most of the regulations (DOE Orders and Code of Federal Regulations) are written for high hazard facilities. By invoking a graded approach to these severe regulations, much is left to interpretation when applied to a facility far removed from those intended in the regulation/order.

When obtaining a Nuclear Facility designation, the increase in level of formality of operations and review is significant. This leads to a concomitant increase in support staff for reviews and regulatory matters. It is difficult to estimate a priori the level of complexity and resource demand required for regulatory compliance issues. TFTR was involved in a number of reviews of documents (e.g., Environmental Assessment, EA, and Final Safety Analysis Report, FSAR and Operational Readiness Reviews, ORRs) see Ref. 3. One key lesson learned is that the facility must take the lead in establishing the interpretation and implementation of applicable regulations/orders and then obtain concurrence from the regulators. A reasonable approach serves to minimize the 
variation in interpretation of the requirements (fewer interpreters) and more timely concurrence and approval.

As a result of reviewing the DOE Order on Conduct of Operations (5480.19), the TFTR operations chain-of-command was strengthened and more clearly defined. It became readily apparent that a nuclear facility required a central point of control under supervision of one operations executive officer. A new position, TFTR Shift Supervisor, was created and is filled by certified engineering staff (under DOE Order 5480.20). The Shift Supervisor is at the top of the TFTR operational chain-of-command and is responsible for keeping track of the facility status and from whom all operations and maintenance authorization must be obtained. This strong central cognizance of facility status is crucial to ensure that incompatible operations and maintenance tasks are avoided. It is also the Shift Supervisor that declares the facility in the appropriate operational mode, permitting movement of tritium.

Another positive lesson in preparing for Nuclear Facility status came from realizing that a comprehensive training program for operators is required for reduced tritium exposure, releases and enhanced personnel safety. Extensive procedure training and practice (through drills) translates into safe, rapid and effective mitigation of problems and emergencies.

\section{B. Commissioning/Maintenance}

During commissioning a number of tritium leaks were detected. The leaks tended to be difficult to locate (especially oxide leaks) due to contamination of nearby surfaces, giving false positive indication by hand held ion chambers. This was abated somewhat by starving the cleanup systems of oxygen, thereby minimizing oxide formation and exposure of personnel to oxide. Most external leaks were found to be in gaskets: elastomeric gaskets permeating tritium; and metal gaskets leaking due to improper installation or thermal cycling. Some valve through-put leaks were observed. Such leaks do not present a direct threat to exposure of personnel, but are considered serious because areas of the system cannot be isolated, giving false indications of leaks or preventing isolation of parts of the system required for maintenance.

During the commissioning phase, the design of the tritium systems led to extreme difficulty in performing corrective and periodic maintenance because of insufficient purge paths and lack of properly implemented joining techniques (UHV flanges). Parts of the system that were found to be defective were repaired and upgraded to facilitate pumping and purging of the systems and components were replaced with more tritium compatible equipment. Similar results were experienced during subsequent periodic and corrective maintenance of the systems.

Whenever the tritium envelope is opened (a line-break), reduction of the tritium concentration is achieved by purging with dry inert gas and followed typically with a room air (moist) purge to reduce the surface contamination of tritium oxide. We found that systems that are easily and quickly maintained greatly reduce complications (exposure, releases) during line-breaks. Ready accessibility (in a glove box or in the open) of components and providing numerous purge paths are key to rapid and efficient maintenance. It is important to realize that speed and efficiency is central to reducing exposure to tritium.

We have also found that modern Ultra High Vacuum (UHV) equipment is ideally suited for use in tritium systems since the two technologies share many basic requirements. UHV components are extensively used in the semiconductor technology field, which has fostered a large demand and, hence, a large industry to provide such equipment. Copper gasketed CF (Conflat) type flanges make simple and reliable joints that are leak and permeation free. These flanges are limited in size and maximum temperature $\left(\approx 400^{\circ} \mathrm{C}\right)$. Supported (spring or trapped gas) metal gaskets require finely finished surfaces, but make extremely reliable seals and are highly resistant to thermal cycling induced creep.

Segregation of low tritium concentration streams from high concentration streams greatly reduces the requirements for purging and hightech components in the low concentration 
streams. Again this efficiency manifests itself in reduced exposure time and therefore in dose.

Another finding was that the rooms exposed to systems leaking HTO developed surface contamination $(\approx 1000-10,000 \mathrm{dpm} / 100 \mathrm{~cm} 2)$ that cleaned-up ( $\approx$ day) with good room air exchange. This result enhances operation since it reduces exposure and eliminates the need for protective clothing after a brief time period.

\section{CALIBRATION OF GHT ION CHAMBER A}

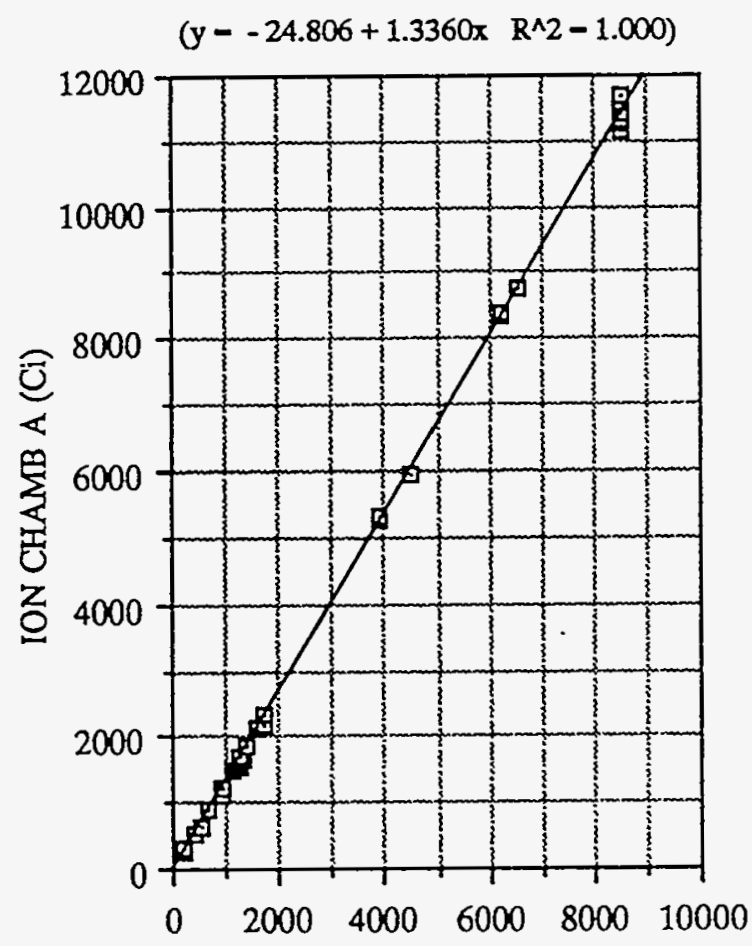

INJECTED ACTIVITY (CI)

Figure 3. GHT Ionization Chamber In-Process Calibration. Data indicate a large systmatic error, but is highly linear with low random error.

\section{Tritium Inventory}

Tritium inventory was recognized early on as a critical task in the overall management of the tritium process. Tritium inventory and accountability methods are mandated by DOE
Order 5633.3 and a series of procedures and a Material Control and Accountability (MC\&A) Plan were developed. This plan called for the daily resolution of all transactions (movements) of tritium from one location to another. This self imposed requirement far exceeded the frequency requirements of the Order. It was recognized, however, that given the small quantities of tritium in use and the large through-put ( $10 \%$ of the site inventory is installed in the injection plena prior to a shot), as well as the $25 \mathrm{kCi}$ limit in any one location, a careful accounting would be required to keep track of events as they happened.

In addition to the accountability issues and the design basis limit, an important research issue required careful tritium accounting. The amount of tritium retained by the tokamak and its ancillary systems has been studied and estimated for several years, both as a general research issue for fusion reactors but also in particular for TFTR given its very low inventory limits. Measurement of the amount of tritium trapped in the tokamak system was recognized as difficult given that is it determined by inventory by difference. By carefully measuring the tritium injected into the neutral beams and the torus (a PVT measurement) and subtracting similarly careful measurements of tritium returned to the GHTs (by sampling the activity and measuring it with one of two parallel plate ionization chambers), a small difference is expected and is a measure of what is retained by the tokamak (primarily in the torus in a codeposited layer.) Any error in these measurements would lead to large errors in the vessel inventory account.

After several weeks of D-T operation (with a hiatus for completion of the shakedown repairs), a discrepancy was detected by a divergence in account balance sheets and delivery vs. shipment balance. It was recognized that on-site inventory was growing relative to the amount calculated by merely subtracting shipments offsite from deliveries on-site. This coupled with the fact that the in-vessel inventory was growing negative (we were measuring more tritium leaving the vessel than was injected) implicated the parallel plate ionization chamber as systematically reading too high. This systematic error would explain the negative balance growing in the torus account and also explain 
the growing on-site inventory. By over reporting the amount of tritium in the DMSBs, we were keeping more tritium on-site than we expected. A physical inventory of the tritium was performed and an in-situ calibration of the flat plate ion chambers were performed.

The major finding of the calibration of the parallel plate ion chambers was that, although they were linear over the tritium concentration range covered at TFTR, the factory calibration was incorrect and that they were systematically reading $30 \%$ too high (see figure 3 .) Using the new calibration numbers the discrepancy disappeared and together with the physical inventory, the accounts were balanced. We are still left, however, with sufficient measurement uncertainty that we cannot draw any definitive conclusions about tritium retention in the vessel.

Several improvements to the process of inventory control and accounting were subsequently made: the role of Nuclear Material Custodian (NMC), the person who tracks and is responsible for tritium movement, was moved to the TFTR Shift Supervisor; strict adherence to daily tritium accounting is enforced; and a comparison of the ion chamber measurements are made on a daily basis to ensure that a large systematic error will not reoccur.

We learned that low inventory limits and high tritium through-put require a high level of (quasi-real-time) tracking. We also learned that the NMC must have sufficient authority to halt operation when required, especially in support of the daily record keeping. Another important lesson was the realization that in-process calibration of primary inventory instrumentation is required to assure accurate measurement.

\section{SUMMARY}

TFTR DT performance has exceeded many world records, including fusion energy production - to $9 \mathrm{MW}$ at this time. Stable operation of the TFTR Tritium Systems has enabled routine DT operation of the machine and has supported this record performance. Approximately $120 \mathrm{kCi}$ of tritium have been safely processed through the system, without significantly challenging the safety envelope or worker exposure. Several key lessons have been learned: well trained workers reduce the risk of exposure; ultra high vacuum techniques and equipment serve well in a tritium environment; and a high level of tracking of tritium must be maintained, especially where the through put is high but the allowed inventory is low.

\section{ACKNOWLEDGMENTS}

This work is supported by US DOE Contract No. DE-ACO2-76-CHO-3073.

\section{REFERENCES}

1. J. Hosea, J. H. Adler, P. D. Alling, et al., "D-T Experiments on TFTR," these proceedings.

2. J.L. Anderson, R.A.P. Sissingh, C.A. Gentile, et al., "Initial Testing of the Tritium Systems at the Tokamak Fusion Test Reactor," 15th Symposium on Fusion Engineering, 1993, IEEE, Hyannis, MA, pp. $208-11$.

4. C.A. Gentile, J. Levine, M. Norris, et al., "The Tokamak Fusion Test Reactor Tritium Systems Test Contractor Operational Readiness Review," 15th Symposium on Fusion Engineering, 1993, IEEE, Hyannis, MA, pp.1023-4 
Dr. F. Paoloni, Univ. of Wollongong, AUSTRALIA

Prof. R.C. Cross, Univ. of Sydney, AUSTRALIA

Plasma Research Lab., Australian Nat. Univ., AUSTRALIA

Prof. I.R. Jones, Flinders Univ, AUSTRALIA

Prof. F. Cap, Inst. for Theoretical Physics, AUSTRIA

Prof. M. Heindler, Institut für Theoretische Physik, AUSTRIA

Prof. M. Goossens, Astronomisch Instituut, BELGIUM

Ecole Royale Militaire, Lab. de Phy. Plasmas, BELGIUM

Commission-European, DG. XII-Fusion Prog., BELGIUM

Prof. R. Bouciqué, Rijksuniversiteit Gent, BELGIUM

Dr. P.H. Sakanaka, Instituto Fisica, BRAZIL

Prof. Dr. I.C. Nascimento, Instituto Fisica, Sao Paulo, BRAZIL Instituto Nacional De Pesquisas Espaciais-INPE, BRAZIL Documents Office, Atomic Energy of Canada Ltd., CANADA Ms. M. Morin, CCFMTTokamak de Varennes, CANADA Dr. M.P. Bachynski, MPB Technologies, Inc., CANADA Dr. H.M. Skarsgard, Univ. of Saskatchewan, CANADA Prof. J. Teichmann, Univ. of Montreal, CANADA Prof. S.R. Sreenivasan, Univ. of Calgary, CANADA Prof. R. Marchand, INRS-Energie et Materiaux, CANADA Dr. R. Bolton, Centre canadien de fusion magnétique, CANADA Dr. C.R. James,, Univ. of Alberta, CANADA

Dr. P. Lukác, Komenského Universzita, CZECHO-SLOVAKIA The Librarian, Culham Laboratory, ENGLAND Library, R61, Rutherford Appleton Laboratory. ENGLAND Mrs. S.A. Hutchinson, JET Library, ENGLAND Dr. S.C. Sharma, Univ. of South Pacific, FIJI ISLANDS

P. Măhönen, Univ. of Helsinki, FINLAND

Prof. M.N. Bussac, Ecole Polytechnique., FRANCE

C. Mouttet, Lab. de Physique des Milieux lonisés, FRANCE

J. Radet, CEN/CADARACHE - Bat 506, FRANCE

Prof. E. Economou, Univ. of Crete, GREECE

Ms. C. Rinni, Univ. of loannina, GREECE

Preprint Library, Hungarian Academy of Sci., HUNGARY

Dr. B. DasGupta, Saha Inst. of Nuclear Physics, INDIA

Dr. P. Kaw, Inst. for Plasma Research, INDIA

Dr. P. Rosenau, Israel Inst. of Technology, ISRAEL Librarian, International Center for Theo Physics, ITALY Miss C. De Palo, Associazione EURATOM-ENEA , ITALY

Dr. G. Grosso, Istituto di Fisica del Plasma, ITALY

Prof. G. Rostangni, Istituto Gas lonizzati Del Cnr, ITALY
Dr. H. Yamato, Toshiba Res \& Devel Center, JAPAN

Prof. I. Kawakami, Hiroshima Univ., JAPAN

Prof. K. Nishikawa, Hiroshima Univ., JAPAN

Librarian, Naka Fusion Research Establishment, JAERI, JAPAN

Director, Japan Atomic Energy Research Inst., JAPAN

Prof. S. Itoh, Kyushu Univ., JAPAN

Research Info. Ctr., National Instit. for Fusion Science, JAPAN

Prof. S. Tanaka, Kyoto Univ., JAPAN

Library, Kyoto Univ., JAPAN

Prof. N. Inoue, Univ. of Tokyo, JAPAN

Secretary, Plasma Section, Electrotechnical Lab., JAPAN

Dr. O. Mitarai, Kumamoto Inst. of Technology, JAPAN

Dr. G.S. Lee, Korea Basic Sci. Ctr., KOREA

J. Hyeon-Sook, Korea Atomic Energy Research Inst., KOREA

D.I. Choi, The Korea Adv. Inst. of Sci. \& Tech., KOREA

Prof. B.S. Liley, Univ, of Waikato, NEW ZEALAND

Inst of Physics, Chinese Acad Sci PEOPLE'S REP. OF CHINA Library. Inst. of Plasma Physics, PEOPLE'S REP. OF CHINA Tsinghua Univ. Library, PEOPLE'S REPUBLIC OF CHINA Z. Li, S.W. Inst Physics, PEOPLE'S REPUBLIC OF CHINA Prof. J.A.C. Cabral, Instituto Superior Tecnico, PORTUGAL Prof. M.A. Hellberg, Univ. of Natal, S. AFRICA Prof. D.E. Kim, Pohang Inst. of Sci. \& Tech., SO. KOREA

Prof. C.I.E.M.A.T, Fusion Division Library, SPAIN

Dr. L. Stenflo, Univ. of UMEA, SWEDEN

Library, Royal inst. of Technology, SWEDEN

Prof. H. Wilhelmson, Chalmers Univ. of Tech., SWEDEN Centre Phys. Des Plasmas, Ecole Polytech, SWITZERLAND Bibliotheek, Inst. Voor Plasma-Fysica. THE NETHERLANDS Asst. Prof. Dr. S. Cakir, Middle East Tech. Univ., TURKEY Dr. V.A. Glukhikh,Sci. Res. Inst. Electrophys.I Apparatus, USSR Dr. D.D. Ryutov, Siberian Branch of Academy of Sci., USSR Dr. G.A. Eliseev, I.V. Kurchatov Inst., USSR Librarian, The Ukr.SSR Academy of Sciences, USSR Dr. L.M. Kovrizhnykh, Inst. of General Physies, USSA Kemforschungsanlage GmbH, Zentralbibliothek, W. GERMANY Bibliothek, Inst. Für Plasmaforschung. W. GERMANY Prof. K. Schindler, Ruhr-Universitát Bochum, W. GERMANY Dr. F. Wagner, (ASDEX), Max-Planck-Institut, W. GERMANY Librarian, Max-Planck-Institut, W. GERMANY 